\title{
SOLUBILITY OF BORON AND CARBON IN FERRITE OF THE Fe-B-C SYSTEM ALLOYS
}

\author{
D Natalia Filonenko ${ }^{1,2}$ \\ ${ }^{1}$ State Institution "Dnipropetrovsk Medical Academy of Health Ministry of Ukraine" \\ 9, Vernadsky Str., Dnipro, 49044, Ukraine \\ ${ }^{2}$ Z.I. Nekrasov Iron and Steel Institute of National Academy of Sciences of Ukraine \\ 1, Akademika Starodubova Square, Dnipro, 49107, Ukraine \\ E-mail:natph2016@gmail.com \\ Received March 11, 2019; revised March 29, 2019; accepted April 12, 2019
}

Investigation was carried out for Fe-B-C alloys with carbon content of $0.0001-0.01 \%$ (wt.) and boron content of $0.0001-0.01 \%$ (wt.), the rest is iron. To determine the structural state of alloys we use the microstructure analysis, X-ray microanalysis and X-ray structure analysis. The level of microstraines, dislocation density and the coercive force of ferrite is determined, and it is shown that structure imperfection grows with boron content increase in the alloy. The obtained results enable to suggest that boron atoms in a solid solution of $\alpha$-iron occupy substitutional-interstitial positions depending on boron content. In the paper it is shown experimentally, that at room temperature solubility limit of boron and carbon in the ferrite is $0.00012 \%$ (wt.) and $0.006 \%$ (wt.). When boron and carbon content increases further, the following phases are formed: $\mathrm{Fe}_{2} \mathrm{~B}, \mathrm{Fe}_{3}(\mathrm{CB})$ and $\mathrm{Fe}_{23}(\mathrm{CB})_{6}$. In this paper by means of quasi-chemical method we obtain for the first time temperature dependence of the free energy for $\alpha$-iron solid solution, as well as solubility limit of carbon and boron. Maximum mass fraction of carbon may be up to $0.016 \%$ (wt.), and maximum boron mass fraction - up to $0.00025 \%$ (wt.). At room temperature the boron solubility limit in ferrite is $0.0001 \%$ (wt.), and carbon one is $0.004 \%$ (wt.). The calculated numerical values of the solubility of boron and carbon in ferrite of the Fe-B-C system alloys are less than that of the experimental results. This can be explained by the fact that boron atoms interact more actively with structure imperfections than carbon atoms. At high temperatures the solubility of carbon and boron in given phase increases.

KEYWORDS: ferrite, solubility of boron and carbon, Fe-B-C system alloys

It is known that boron has a low solubility in iron-based solid solutions [1-2], but authors suggest different values for boron solubility in $\alpha$-iron solid solution of the Fe-B system. Thus, authors of work [1] indicate that boron solubility in solid solution of $\alpha$-iron in the Fe-B system is $0.004 \%$ (wt.) at $983 \mathrm{~K}$, and $0.08 \%$ (wt.) at $1179 \mathrm{~K}$. The authors of [2] note that the maximum solubility of boron in ferrite is $0.002 \%$ (wt.) at the temperature of $1184 \mathrm{~K}$. The other solubility of boron is pointed out by the authors of Ref. [3]: from $0.0035 \%$ (wt.) to $0.00000038 \%$ (wt.) when the temperature decreases from $1179 \mathrm{~K}$ to $983 \mathrm{~K}$. In [4] the boron solubility is $0.0003-0.0067 \%(\mathrm{wt})$. The authors of [5] report the numerical value of boron solubility is $0.0019 \%$ (wt.) at the temperature of $773 \mathrm{~K}$.

According to [2], the boron solubility in $\delta$-iron is $0.15 \%$ (wt.), and according to [3] $-0.16 \%$ (wt).

It is known that maximum solubility of carbon in the Fe-C system in $\delta$-iron is $0.1 \%$ (wt.) at $1772 \mathrm{~K}$, and in $\alpha$ iron $-0.02 \%$ at $973 \mathrm{~K}$, and $0.01 \%$ (wt.) at room temperature [6-7], whilst the authors of work [3] note the value $0.025 \%$ (wt.) at the temperature of $996 \mathrm{~K}$.

At the moment, there is no information in the literature on the solubility limits of boron and carbon in $\alpha$-iron of the Fe-B-C alloys. alloys.

The objective of this paper is to determine the solubility limits of boron and carbon in ferrite of the Fe-B-C system

\section{MATERIALS AND METHODS}

Investigation was carried out for the specimens with carbon content of $0.0001-0.01 \%$ (wt.) and boron content of $0.0001-0.01 \%$ (wt.), the rest is iron. The following components were used to obtain the Fe-B-C system alloys: carbonyl iron (with iron content of $99.95 \%$ (wt.)), amorphous boron (with boron content of $97.50 \%$ (wt.)), graphite (with carbon content of $99.96 \%$ (wt.)). Smelting of specimens was performed in a Taman furnace with in alundum crucibles in argon atmosphere. The cooling rate of alloys was $10 \mathrm{~K} / \mathrm{s}$. To determine the chemical composition of alloys, chemical and spectral analysis was used [8]. Microhardness was measured by PMT-3 device.

The phase composition of alloys was determined by X-ray microanalysis by means of JSM-6490 microscope with ASID-4D scanning head and "Link Systems 860" software energy-dispersive X-ray microanalyser, as well as by means of optical microscope "Neophot-21". X-ray electron probe analysis was carried out using internal standards. The X-ray and X-ray diffraction analysis was performed with DRON-3 diffractometer in monochromated Fe-K $\mathrm{K}_{\alpha}$ radiation.

\section{RESULTS AND DISCUSSION}

The study of boron and carbon content in the Fe-B-C system alloys shows that boron and carbon maximum content in $\alpha$-iron solid solution at room temperature can take such numeric values: $0.00012 \%$ (wt.) and $0.006 \%$ (wt.). At this boron and carbon content there is no formation of boron- and carbon-bearing phases except for ferrite (Fig. 1). 
With boron content increase in alloy there boride are formed on the boundaries of ferrite grains, and with carbon content increase in alloy the formation of pearlite on the boundaries of ferrite grains occurs (Fig. 2).

If the content of boron or carbon in the alloy is greater than $0.0012 \mathrm{wt} . \%$ (boron) $0.004 \mathrm{wt}$. \% (carbon), then the $\mathrm{Fe}_{2} \mathrm{~B}, \mathrm{Fe}_{3}(\mathrm{CB}), \mathrm{Fe}_{23}(\mathrm{CB})_{6}$ phases are formed in the alloy [9].

It is known that the lattice parameter of bcc iron at room temperature is $2.862 \AA$ [6]. Under boron and carbon doping of alloys the change in the lattice parameter of ferrite is observed (Table 1).

The results shown in Table enable to qualitatively evaluate the structure imperfection of ferrite depending on content of boron and carbon in the alloy. As boron content increases in the alloy, the microstrain degree, the density of dislocations in ferrite and the coercive force grows.

An increase in the coercive force for alloys containing higher content of boron and carbon can be explained by change in the density of dislocations and decrease in the size of the crystallites. The results (Table 1) show unique correlation relationship between the characteristics of the $H_{\mathrm{c}}$, on the one hand, and the microstrain degree and density of dislocations, on the other hand, in all the specimens examined.

In addition, the results represented in Table 1 show that doping of ferrite only with boron leads to increase in the size of crystallites $L$, the density of dislocations $\rho$, the microstrain degree and the coercive force $H_{\mathrm{c}}$ compared with carbon doping. The obtained results can be explained by the fact that boron atoms in $\alpha$-iron solid solution occupy substitutional-interstitial positions depending on boron content, which is in line with the results of other authors [10-11].

The structure of ferrite represents as body-centered lattice and pertains to the space group $O_{h}^{9}-\operatorname{Im} 3 \mathrm{~m}$ with eight atoms in the first coordination shell [12]. For each atom of the bcc lattice there are six tetrahedral and three octahedral pores. Two of the six atoms surrounding the octahedral pore, are closest compared to others [13]. The arrangement of carbon atoms in the bcc lattice can be described as the arrangement of the atoms of carbon or boron in the octahedral pore, which have four nearest metal atoms at a distance of $2.02 \AA$ and two at the distance of $1.43 \AA$, each metal atom has eight neighbors located at the distance of $2.48 \AA$ Á from each other (Fig. 3).

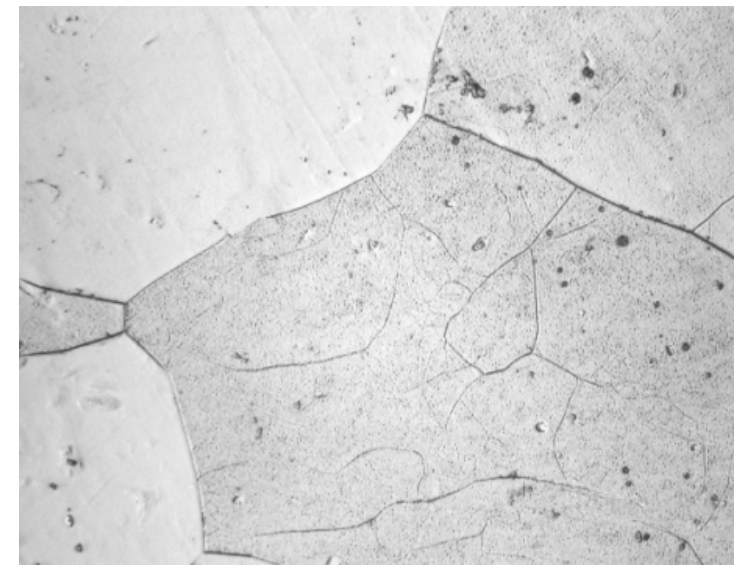

a

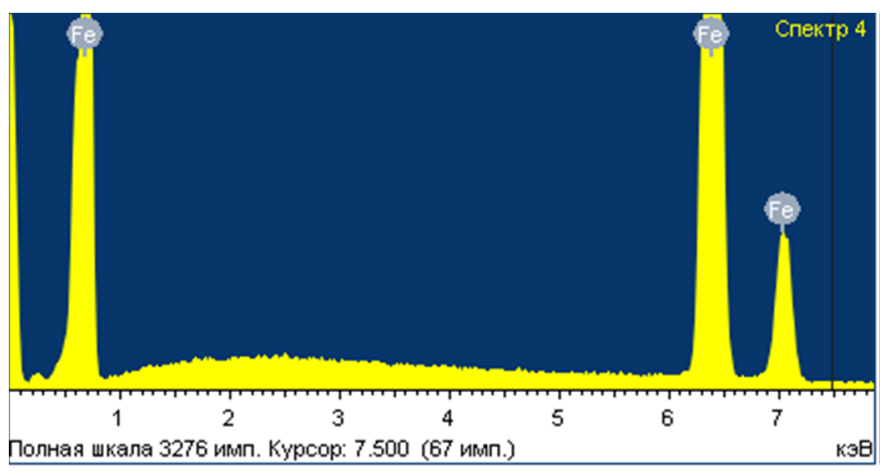

b

$I_{\text {imp/s }}$

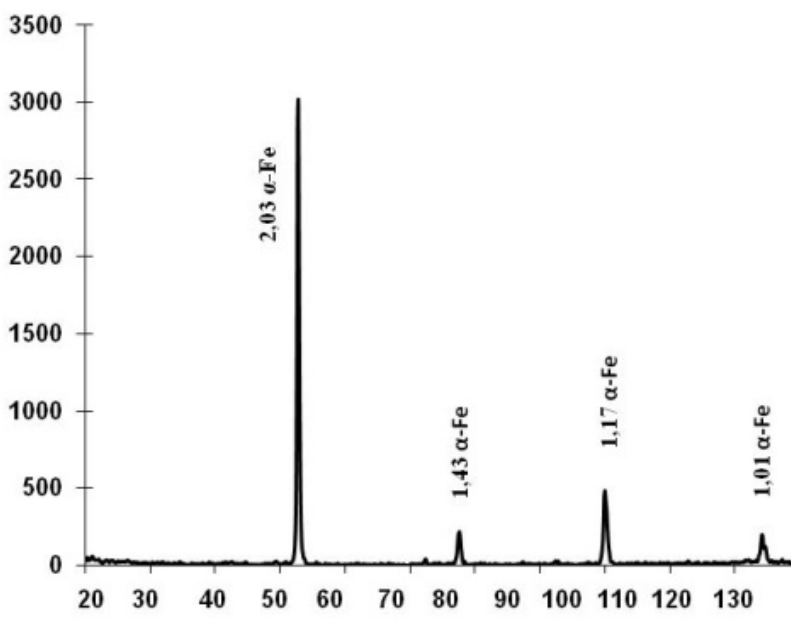

c

Fig. 1. Iron-based alloy with boron content of $0.0012 \%$ (wt.) and carbon content of $0.004 \%$ (wt.): a) microstructure, $\times 800$, b) microspectrum analysis curve, c) diffractogram 


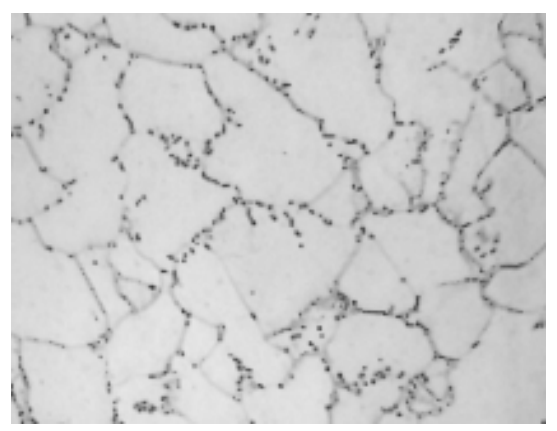

a

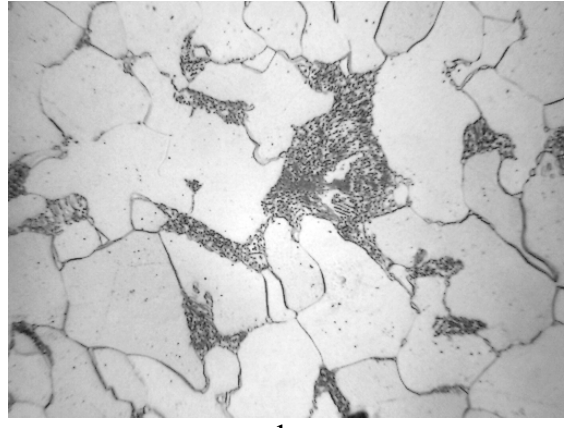

b

Fig. 2. Microstructure of alloys with: a) $0.005 \%$ (wt.) boron and $0.004 \%$ (wt.) carbon, b) $0.0012 \%$ (wt.) boron and $0.04 \%$ (wt.) carbon, $\times 500$

Table 1

Dependence of lattice parameter of ferrite $a$, crystallite size $L$, density of dislocations $\rho$, microstrain degree and coercive force $H_{c}$ in ferrite on the boron and carbon content in alloy

\begin{tabular}{|c|c|c|c|c|c|c|}
\hline \multicolumn{2}{|c|}{ Content, \% (wt.) } & \multirow[t]{2}{*}{$a, \AA$} & \multirow[t]{2}{*}{$\mathrm{H}_{\mathrm{c}}, \mathrm{A} / \mathrm{cm}$} & \multirow[t]{2}{*}{$L, \AA$} & \multirow{2}{*}{$\begin{array}{c}\text { Microstrain } \\
\text { degree of ferrite }\end{array}$} & \multirow[t]{2}{*}{$\rho, \mathrm{cm}^{-2}$} \\
\hline Boron & Carbon & & & & & \\
\hline 0.0001 & 0.001 & 2.8614 & 4.6 & 1006 & $4.84 \cdot 10^{-4}$ & $6.91 \cdot 10^{10}$ \\
\hline 0.0001 & 0.005 & 2.8610 & 5.8 & 1097 & $4.98 \cdot 10^{-4}$ & $7.52 \cdot 10^{10}$ \\
\hline 0.001 & 0.001 & 2.8623 & 6.9 & 1114 & $5.62 \cdot 10^{-4}$ & $4.77 \cdot 10^{10}$ \\
\hline 0.001 & 0.005 & 2.8629 & 7.54 & 1230 & $5.23 \cdot 10^{-4}$ & $9.82 \cdot 10^{10}$ \\
\hline 0.005 & 0.001 & 2.8633 & 8.21 & 1098 & $6.45 \cdot 10^{-3}$ & $10.1 \cdot 10^{10}$ \\
\hline 0.005 & 0.01 & 2.8642 & 8.97 & 1087 & $7.62 \cdot 10^{-3}$ & $10.48 \cdot 10^{10}$ \\
\hline 0.0001 & - & 2.8650 & 4.2 & 1123 & $2.5 \cdot 10^{-3}$ & $7.2 \cdot 10^{10}$ \\
\hline- & 0.001 & 2.8616 & 3.9 & 1056 & $1.11 \cdot 10^{-3}$ & $2.3 \cdot 10^{10}$ \\
\hline
\end{tabular}

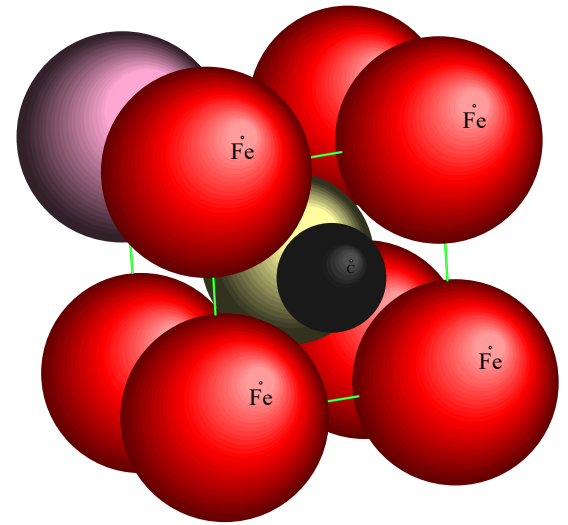

Fig. 3. Structure of ferrite

To calculate the solubility limit of carbon and boron atoms in the ferrite lattice, we use the quasi-chemical method with accounting for data on the boron and carbon position in $\alpha$-iron solid solution [14].

The interaction of Fe-Fe, Fe-C, Fe-B and Fe-V atoms (where $\mathrm{V}$ is vacancy) can be taken into consideration as follows: the energy of interaction between eight atoms at the distance of $2.48 \AA$ is $v_{\mathrm{FeFe}}, v_{\mathrm{FeB}_{1}}, v_{\mathrm{FeV}}$, between atoms at the distance of $2.02 \AA-v_{\mathrm{FeC}}, v_{\mathrm{FeB}_{2}}, v_{\mathrm{FeV}_{1}}$, and for two carbon or boron atoms located at the distance of $1.43 \AA-v_{\mathrm{FeC}}^{\prime}, v_{\mathrm{FeV}_{1}}^{\prime}$ and $v_{\mathrm{Fe} B_{2}}^{\prime}$. For the values of the interaction energy of the atomic pairs, we use the results given in [9].

The free energy of ferrite can be determined by the formula $F=E-k T \ln W$, where $E$ is the internal, $W$ is the thermodynamic probability of the atom location in the sites of the ferrite crystal lattice, $k=1.38 \cdot 10^{-23} \mathrm{~J} / \mathrm{K}$ is Boltzmann constant, $T$ is absolute temperature.

Thus, the free energy of ferrite is found as:

$F=-\sum_{i=1}^{8}\left(N_{F e} N_{B_{1}} v_{F e B_{1}}+N_{F e} N_{F e} v_{F e F e}+N_{V} N_{F e} v_{F e V}\right)-\sum_{i=1}^{4}\left(N_{F e} N_{C} v_{F e C}+N_{F e} N_{B_{2}} v_{F e B_{2}}+N_{F e} N_{V_{1}} v_{F e V_{1}}\right)-$

$-\sum_{i=1}^{2}\left(N_{F e} N_{C} v_{F e C}^{\prime}+N_{F e} N_{B_{2}} v_{F e B_{2}}^{\prime}+N_{F e} N_{V_{1}} v_{F e V_{1}}^{\prime}\right)-$

$-k T\left(\left(N_{\mathrm{V}}+N_{F e}+N_{B}\right)\left(\ln \left(N_{\mathrm{v}}+N_{F e}+N_{B}\right)-1\right)-N_{F e}\left(\ln N_{F e}-1\right)+N_{V}\left(\ln \left(N_{V}-1\right)-\right.\right.$

$-N_{B_{1}}\left(\ln N_{B_{1}}-1\right)+\left(N_{V_{1}}+N_{C}+N_{B_{2}}\right)\left(\ln \left(N_{V_{1}}+N_{C}+N_{B_{2}}\right)-1\right)-N_{C}\left(\ln N_{C}-1\right)-$

$-N_{B_{2}}\left(\ln N_{B_{2}}-1\right)-N_{V_{1}}\left(\ln \left(N_{V_{1}}-1\right)\right)$,

where $N_{B}=N_{B_{1}}+N_{B_{2}}$ is the number of boron atoms. 
To calculate the solubility of carbon and boron in ferrite, we should find the solution of set of equations:

$$
\frac{\partial F}{\partial N_{F e}}=0, \frac{\partial F}{\partial N_{C}}=0, \frac{\partial F}{\partial N_{B_{2}}}=0, \frac{\partial F}{\partial N_{B_{1}}}=0, \frac{\partial F}{\partial N_{V}}=0 \text { and } \frac{\partial F}{\partial N_{V_{1}}}=0
$$

The obtained set of equations (1) is transcendental. Usually the solution of such equations can be obtained graphically or numerically. But within this problem there is a good reason to consider an asymptotic solution of the equations. For this we write the logarithm appeared in each equation of the system (1) as Taylor expansion (this is admissible in accordance with its convergence conditions):

$$
\begin{aligned}
& \frac{\partial F}{\partial N_{F e}}=-\sum_{i=1}^{8} N_{B} v_{F e B_{1}}+2 N_{F e} v_{F e F e}-\sum_{i=1}^{4}\left(N_{C} v_{F e C}+N_{V} v_{F e V}\right)- \\
& -\sum_{i=1}^{2}\left(N_{C} v_{F e C}^{\prime}+N_{V_{1}} v_{F e V_{1}}^{\prime}\right)-k T\left(\frac{(-1)^{n-1}\left(N_{F e}\right)^{n}}{n}+\sum_{n=1}^{\infty} \frac{(-1)^{n}\left(N_{F e}\right)^{n+1}}{\left(N_{V}+N_{B}\right)^{n+1}(n+1)}+\sum_{n=1}^{\infty} \frac{(-1)^{n}\left(N_{F e}-1\right)^{n}}{n}\right)=0 \\
& \frac{\partial F}{\partial N_{C}}=-\sum_{i=1}^{4}\left(N_{C} v_{F e C}\right)-\sum_{i=1}^{2}\left(N_{C} v_{F e C}^{\prime}\right)-k T\left(\frac{(-1)^{n-1}\left(N_{C}\right)^{n}}{n}+\sum_{n=1}^{\infty} \frac{(-1)^{n}\left(N_{C}\right)^{n+1}}{\left(N_{V_{1}}+N_{B_{2}}\right)^{n+1}(n+1)}+\right. \\
& \left.+\sum_{n=1}^{\infty} \frac{(-1)^{n}\left(N_{C}-1\right)^{n}}{n}\right)=0 \\
& \frac{\partial F}{\partial N_{B_{1}}}=-\sum_{i=1}^{8}\left(N_{F e} v_{F e B_{1}}\right)-\sum_{i=1}^{4}\left(N_{F e} v_{F e B_{2}}\right)-\sum_{i=1}^{2}\left(N_{F e} v_{F e B_{2}}^{\prime}\right)-k T\left(\sum_{n=1}^{\infty} \frac{(-1)^{n}\left(N_{B_{1}}-1\right)^{n}}{n}=0 ;\right. \\
& \frac{\partial F}{\partial N_{B_{2}}}=-\sum_{i=1}^{4}\left(N_{B_{2}} v_{F e B_{2}}^{\prime}\right)-\sum_{i=1}^{2}\left(N_{B_{2}} v_{F e B_{2}}^{\prime}\right)-k T\left(\frac{(-1)^{n-1}\left(N_{B_{2}}\right)^{n}}{n}+\sum_{n=1}^{\infty} \frac{\left.(-1)^{n}\left(N_{B_{2}}\right)^{n+1}+N_{C}\right)^{n+1}(n+1)}{(n+}+\right. \\
& \left.+\sum_{n=1}^{\infty} \frac{(-1)^{n}\left(N_{B_{2}}-1\right)^{n}}{n}\right)=0 . \\
& \frac{\partial F}{\partial N_{V}}=-8 N_{F e} v_{F e V}-k T\left(\frac{(-1)^{n-1}\left(N_{V}\right)^{n}}{n}+\sum_{n=1}^{\infty} \frac{(-1)^{n}\left(N_{V}-1\right)^{n+1}}{\left(N_{F e}+N_{B}\right)^{n+1}(n+1)}+\sum_{n=1}^{\infty} \frac{(-1)^{n}\left(N_{V}-1\right)^{n}}{n}=0\right. \\
& \frac{\partial F}{\partial N_{V_{1}}}=-4 N_{F e} v_{F e V_{1}}-2 N_{F e} v_{F e V_{1}}^{\prime}-k T\left(\frac{(-1)^{n-1}\left(N_{V_{1}}\right)^{n}}{n}+\sum_{n=1}^{\infty} \frac{(-1)^{n}\left(N_{V_{1}}-1\right)^{n+1}}{\left(N_{C}+N_{B_{2}}\right)^{n+1}(n+1)}+\right. \\
& \left.+\sum_{n=1}^{\infty} \frac{(-1)^{n}\left(N_{V_{1}}-1\right)^{n}}{n}\right)=0 .
\end{aligned}
$$

To obtain an asymptotic estimate of the system (2) solution, it is quite sufficient to consider the first two terms of the logarithm expansion.

The results of solving of the set of equations are presented in Fig. 4.

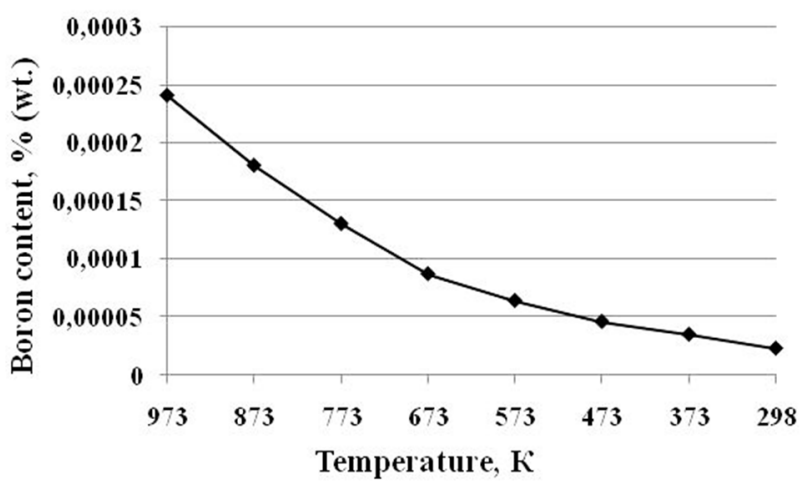

a

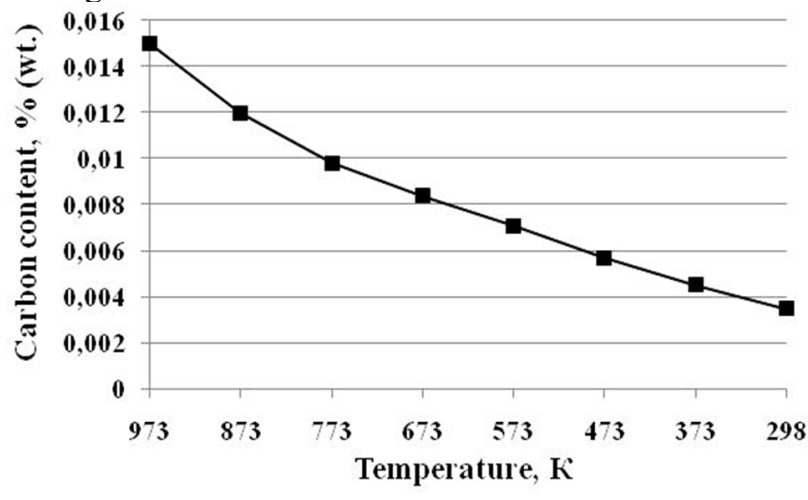

b

Fig. 4. Content of boron (a), carbon(b) in $\alpha$-iron solid solution

The solubility of carbon in $\delta$-iron is estimated to be $0.062 \%$ (wt.) and boron solubility is $0.15 \%$ (wt.). The analysis of the results enables to determine the solubility of carbon and boron in ferrite: it was revealed that up to $0.016 \%$ (wt.) of carbon atoms can get into the pores in the ferrite lattice depending on temperature. According to the 
calculations, the maximum content of boron in ferrite can be up to $0.00025 \%$ (wt.). At room temperature the boron solubility in ferrite is $0.0001 \%$ (wt.), and the carbon one is $0.004 \%$ (wt.). The obtained results can be explained by the fact that boron doping of the iron-based alloys leads to displacement of the eutectoid point to the left in the state diagram of $\mathrm{Fe}-\mathrm{C}$ and to the increase in the pearlite volume ratio, meaning, the carbon atom more likely to be located surrounded by iron atoms than by boron atoms [10-11]. Besides, boron atoms in the position of interstitial into the crystal lattice of $\alpha$-iron have a greater binding energy with iron atoms than that with carbon atoms [10-11]. The effect of boron atoms in the position of interstitial in $\alpha$-iron solid-solution on carbon atoms promotes the formation around the boron atoms of carbon-depleted zones [10-11]. The resulting values of the solubility of boron and carbon in ferrite of the Fe-B-C system alloys are less than those of other authors. This can be explained by the fact that boron is a horophilic element and interacting more actively with dislocations than carbon atoms [15]. Therefore, according to the results of experimental studies, the values of carbon and boron content is slightly higher.

\section{CONCLUSION}

It was shown that the solubility limit of boron and carbon in $\alpha$-iron solid solution according to experimental data is $0.00012 \%$ (wt.) and $0.006 \%$ (wt.) at room temperature. As boron and carbon content grows, the formation of $\mathrm{Fe}_{2} \mathrm{~B}$, $\mathrm{Fe}_{3}(\mathrm{CB}), \mathrm{Fe}_{23}(\mathrm{CB})_{6}$ phases occurs.

In the paper, using the quasi-chemical method, the temperature dependence of the free energy of $\alpha$-iron solid solution is determined for the first time, as well as the solubility limit of carbon and boron in ferrite is calculated. The ferrite can contain up to $0.016 \%$ (wt.) of carbon, and up to $0.00025 \%$ (wt.) of boron, depending on the temperature. At high temperatures the solubility of carbon and boron in this phase increases.

The work was performed within the specific project "Resurs" KC063.18 "Development of chemical composition and technological decisions for the manufacture of railway wheels for different application and their maintainability" of the NAS of Ukraine.

Natalia Filonenko ${ }^{(1)}$ https://orcid.org/0000-0003-1219-348X

\section{ORCID IDs}

\section{REFERENCES}

[1]. N.P. Lyakishev, Yu.L. Pliner and S.I. Lappo, Борсодержащие стали и сплавы [Boron-bearing steels and alloys] (Metallurgiya, Moscow, 1986), p.191. (in Russian)

[2]. A.E. Vol, Строение и свойства металлических систем [Structureand properties of binary metalsystems], (Fizmatgiz, Moscow, 1959), p. 856. (in Russian)

[3]. O.A. Bannykh and M.E. Drytsa, Диаграммы состояния двойных и многокомпонентных систем на основежелеза [Рһале Diagrams of Binary and multicomponent Systems based on of the iron: Handbook], (Metallurgiya, Moscow, 1986), p. 439.

[4]. Yu.B. Kuzma and N.F. Chaban, Двойные и тройньесистемы, содержащие бор: Справочник [Boron-bearing binary and ternary systems], (Metallurgiya, Moscow, 1990), p. 317. (in Russian)

[5]. N.P. Lyakishev, Диаграммы состояния двойных металлических систем: Справочник [Phase Diagrams of Binary Metal Systems: Handbook], (Mashinostroenie, Moscow, 2001), p. 498. (in Russian)

[6]. A.P. Huliaev and A.A. Huliaev, Металловедение [Metalsscience] (Midalliance, 2011), p. 644 c. (in Russian)

[7]. B.N. Arzamasov, V.Y. Makarova and H.H. Mukhynandetc., Металловедение [Metalsscience] (Moscow, BMSTU, 2001), p. 648. (in Russian)

[8]. S.V. Tverdokhlebova, Vìsnik Dnìpropetrovs'kogo unìversitetu. Serìa Fìzika, radìoelektronìka, 14(12/1) 100-104 (2007). (in Russian)

[9]. O.Yu. Bereza, N.Yu. Filonenko and O.S. Baskevich, Physics and Chemistry of Solid State, 13(3), 968-973 (2012).

[10]. N.Yu. Filonenko and I.M. Spiridonova Physics and Chemistry of Solid State, 10(3), 609-612 (2009).

[11]. N.Yu. Filonenko, O.S. Baskevych and V.V. Soboliev Journal Scientific Bulletin of National Mining University, 4, 74-78 (2012).

[12]. M.P. Shaskolskaya, Кристаллография [Crystallography], (Vysshaya Shkola, Moscow, 1984), p.376. (inRussian)

[13]. Iu.S. Nechaev, Advances in Physical Sciences, 181(5), 493-490 (2011).

[14]. Z.A.Matysina and M.I. Milyan Tеория растворимости примеси в упорядоченныхх фазах [Solubility theory residual element in orderedphase]. (DGU, Dnepro, 1991). p.180.(in Russian)

[15]. V.H. Havrylova, Y.F. Tkachenko and A.V. Belostochnyi, Reporter of the Priazovskyi State Technical University. Section: Technical sciences, 18, 90-95 (2008).

\section{РОЗЧИННІСТЬ БОРУ ТА КАРБОНУ В ФЕРИТІ СПЛАВІВ СИСТЕМИ Ғе-В-С} Н.Ю. Філоненко ${ }^{1,2}$

${ }^{1}$ ДЗ «Дніпропетровська державна медична академія МОЗ України» 49044, Україна, м. Дніпро, вул. Володимира Вернадського, 9

${ }^{2}$ Інститут чорної металургї ім. 3.I. Некрасова НАН України (ІЧМ НАНУ) 49107, Україна, м. Дніпро, пл. Ак. Стародубова К.Ф., 1

Дослідження проводили на сплавах системи Fe-B-C з вмістом карбону 0,0001-0,01 \% (мас.) і бору 0,0001-0,01 \% (мас.), інше - залізо. Для визначення структурного стану сплавів використовували мікроструктурний, мікрорентгеноспектральний та рентгеноструктурний аналізи. Визначено рівень мікронапружень, щільність дислокацій та коерцитивна сила фериту та показано, що зі збільшенням вмісту бору в сплаві дефектність структури зростає. Отримані результати дозволяють висунути 
припущення, що атоми бору в твердому розчині $\alpha$-заліза в залежності від вмісту бору займають позиції проникненнязаміщення. В даній роботі експериментально показано, що при кімнатній температурі межа розчинності бору та карбону в фериті складає 0,00012 \% (мас.) та 0,006 \% (мас.). При подальшому збільшенні вмісту бору та карбону відбувається утворення наступних фаз $\mathrm{Fe}_{2} \mathrm{~B}, \mathrm{Fe}_{3}(\mathrm{CB}), \mathrm{Fe}_{23}(\mathrm{CB})_{6}$. В роботі вперше з застосуванням квазіхімічного методу отримано залежність вільної енергії твердого розчину на основі $\alpha$-заліза від температури та визначено межу розчинності карбону та бору. Максимальна масова частка карбону може складати до 0,016 \% (мас.), а бору до 0,00025 \% (мас.). При кімнатній температурі межа розчинності бору в фериті складає $0,0001 \%$ (мас.), а карбону $0,004 \%$ (мас.). Розраховані числові значення розчинності бору та карбону в фериті сплавів системи Fe-B-C мають менші числові значення ніж за експериментальними результатами. Це можна пояснити тим, що атоми бору більш активно взаємодіє з дефектами структури ніж атоми карбону. Зі збільшенням температури розчинність карбону та бору в даній фазі зростає.

КЛЮЧОВІ СЛОВА: ферит, розчинність бору та карбону, сплави системи Fe-B-C.

\section{РАСТВОРИМОСТЬ БОРА И УГЛЕРОДА В ФЕРРИТЕ СПЛАВОВ СИСТЕМЫ Ғе-В-С Н.Ю. Филоненко ${ }^{1,2}$}

${ }^{I} Г У$ «Днепропетровская государственная медииинская академия МОЗ Украины»" 49044, Украина, г. Днепр, ул. Владимира Вернадского, 9

${ }^{2}$ Институт черной металлургии им. 3.И. Некрасова НАН Украины (ИЧМ НАНУ) 49107, Украина, г. Днепр, ул. Ак. Стародубова К.Ф., 1

Исследования проводились на сплавах системы Fе-В-С с содержанием углерода 0,0001-0,01\% (мас.), бора 0,0001$0,01 \%$ (мас.), остальное - железо. Для определения структурного состояния сплавов использовали микроструктурный, микрорентгеноспектральный и рентгеноструктурный анализы. Определен уровень микронапряжений, плотности дислокаций и коэрцитивная сила феррита и показано, что с увеличением содержания бора в сплаве дефектность структуры увеличивается. Полученные результаты позволяют выдвинуть предположение, что атомы бора в твердом растворе $\alpha$-железа в зависимости от содержания занимают позиции проникновения-замещения. В работе экспериментально показано, что при комнатной температуре предельное содержание бора и углерода в твёрдом растворе феррита составляет $0,00012 \%$ (мас.) и 0,006 \% (мас.). При дальнейшем повышении содержания бора и углерода образуются следующие фазы: $\mathrm{Fe}_{2} \mathrm{~B}, \mathrm{Fe}_{3}(\mathrm{CB})$, $\mathrm{Fe}_{23}(\mathrm{CB})_{6}$. В работе впервые с применением квазихимического метода получили зависимость свободной энергии твердого раствора на основе $\alpha$-железа от температуры и определили предел растворимости углерода и бора. Максимальное массовое содержание углерода при комнатной температуре может составлять до 0,016 \% (мас.), а бор до 0,00025 \% (мас.). При комнатной температуре предел растворимости бора в феррите составляет 0,0001 \% (мас.), а углерода $0,004 \%$ (мас.). Рассчитанные значения растворимости бора и углерода в феррите сплавов системы Fe-B-C имеют меньшие числовое значение, чем по результатам эксперимента. Это можно объяснить тем, что атомы бора более активно взаимодействуют с дефектами структуры, чем атомы углерода. С повышением температуры растворимость углерода и бора в данной фазе увеличивается.

КЛЮЧЕВЫЕ СЛОВА: феррит, растворимость бора и углерода, сплавы системы Fe-B-C 